\title{
2
}

PROJECT MUSE

\section{Administering Interpretation}

Peter Goodrich, Michel Rosenfeld, Giovanna Borradori, Marinos Diamantides, Allen Feldman, Stanley Fish

Published by Fordham University Press

Goodrich, Peter, et al.

Administering Interpretation: Derrida, Agamben, and the Political Theology of Law.

Fordham University Press, 2019.

Project MUSE. muse.jhu.edu/book/65158.

$\Rightarrow$ For additional information about this book https://muse.jhu.edu/book/65158 


\title{
Derrida's Shylock
}

\section{The Life and the Letter of the Law}

\author{
Katrin Trüstedt
}

In "What Is a 'Relevant' Translation," a text that was first published in Critical Inquiry in 200I, Jacques Derrida unfolds a reflection on the problem of translation that departs from a phrase from Shakespeare's Merchant of Venice: "Mercy seasons Justice." This phrase serves as a starting point both for the introduction of an unusual translation and for a general reflection on translation itself. Derrida proposes the translation "Le pardon relève la justice," in which the verb "to season" is translated by "relever" and, as such, related to the movement of translation: "seasoning" is understood in terms of a movement of trans- or sublation. Following Derrida's title, the verb refers to a specific qualification or type of translation: a "relevant" translation.

What distinguishes this type of translation? Relever is the term that Derrida had also proposed some decades ago as the translation for G. W. F. Hegel's notion of Aufhebung. In using relever as the name for the movement of translation, Derrida is thus linking the movement of translation to 
the transformation of Hegelian Aufhebung. A "relevant" translation is one that sublates the translated original in a new medium, that means: negates, elevates, and preserves the original in a new form. Translated back from Derrida's French translation of Shakespeare, "Mercy seasons justice" thus reads: "Mercy elevates and interiorizes, thereby preserves and negates, justice (or the law)." With this elaboration, Derrida ultimately suggests that "mercy" is in some way a "relevant"- that is, a transformative and at the same time a true-translation of justice. This translation would thus be limited only in the way every relevant translation is. But what does it mean, that mercy "sublates" justice or, more precisely in this context, the law? What does it mean that the law is in need of sublation? And what would it mean for the law in this very particular, Shylock's, case, to be in need of sublation and to be "sublated"?

The relation of law and mercy that informs The Merchant of Venice is usually understood in the context of a larger narrative: the narrative of the opposition between a supposedly "Jewish" obedience to the "letter of the law" and a Christian spirit of mercy, which is regarded as a sublation-a negation and elevation — of the Jewish relation to the law. According to this reading, Christian spirit exhibits, as Hegel puts it, "that which fulfils the law but annuls it as law [aufhebt] and so is something higher than obedience to law and makes law superfluous." ${ }^{3}$ The ever-insisting, quasi-allegorical reading of the play thus frames the opposition of a Jewish law and a Christian mercy in such a way. Take Katharine Eisaman Maus's introduction to the play as an example for this type of contextualization:

The opposition between the Christians and Shylock seems rooted in religious disparities. Judaism in the play is presented . . . as a sixteenthcentury Christian like Shakespeare would have construed it, as a set of dramatically vivid contrasts with Christian norms. The law of Moses, as set down in Deuteronomy and Leviticus, specifies numerous aspects of the observant Jew's life.... The Mosaic code places a high value upon justice and emphasizes the importance of adhering to the letter of the law. Shylock's Judaism reveals itself . . in his trust of literal meanings, his respect for observable facts, his expectation that contracts will be rigorously enforced. The typical Christian outlook is different. Christians obtain divine approval not by wearing certain garments, avoiding certain foods, or circumcising their boys, but by believing in Christ's power to save them. The central virtues in this religious system are not justice and 
scrupulous compliance with the law but charity, mercy, and a willingness to believe what seems incredible. ${ }^{4}$

This opposition between "sticking to the letter of the law" and a "scrupulous compliance with the law" in its "literal meanings," on the one hand, and "charity," "mercy," and "faith," on the other, is of course referring to Paul's famous distinction between a supposedly dead "letter of the law" and a living spirit of internalized law, or love. "The letter kills, but the spirit gives life" (2 Cor. 3:6). ${ }^{6}$ Derrida also touches on this opposition in his reflection on Portia's "Mercy seasons justice," even if in passing:

[Portia] tries to convert him [Shylock] to Christianity by persuading him of the supposedly Christian interpretation that consists of interiorizing, spiritualizing, idealizing what among Jews (it is often said, at least, that this is a very powerful stereotype) will remain physical, external, literal, devoted to a respect for the letter. As with the difference between the circumcision of the flesh and the Pauline circumcision of the heart - there will certainly be a need to look for a translation, in the broad sense, with regard to this problematic of circumcision (literal circumcision of the flesh versus ideal and interior circumcision of the heart, Jewish circumcision versus Christian circumcision, the whole debate surrounding Paul). ${ }^{7}$

What distinguishes the type of translation that Derrida develops in "What Is a 'Relevant' Translation?" is the proximity to this Paulinian model of opposition, sublation, and conversion. Derrida seems to rely on Hegel's The Spirit of Christianity and Its Fate, when he characterizes this dynamic as one of Aufhebung or sublation: "interiorizing, spiritualizing, idealizing what ... will remain physical, external, literal, devoted to a respect for the letter." ${ }^{8}$ Yet he relies on Walter Benjamin when he characterizes it also as a form of translation that accounts for what is lost in the process, and thereby for the element of negativity inherent in it:

What the translation with the word "relevant" also demonstrates ... is that every translation should be relevant by vocation. It would thus guarantee the survival of the body of the original (survival in the double sense that Benjamin gives it in "The Task of the Translator," fortleben and überleben: prolonged life, continuous life, living on, but also life after death). Isn't this what a translation does? Doesn't it guarantee these two survivals by losing the flesh during a process of conversion (change)? 
By elevating the signifier to its meaning or value, all the while preserving the mournful and debt-laden memory of the singular body, the first body, the unique body that the translation thus elevates, preserves, and negates (relève)?

Although the general idea of a relevant translation that Derrida draws from Portia's phrase is indeed compelling, the particular example that he draws it from, "Mercy seasons justice," is actually not a "relevant translation" in his own terms. To think of Portia's mercy as a relevant translation of justice in Derrida's sense seems to buy into Portia's own problematic description of the central opposition of letter and spirit and misses a possible alternative reading (and deconstruction) of it. In characterizing the act of mercy Portia proposes as a relevant translation of justice, Derrida suggests that this mercy comes only with the type of loss that accompanies every translation as such, and therefore misses the specific losses and costs that Portia's act of translation produces. With his reference to Benjamin, Derrida seems to propose that this translation implies a certain mournful preservation of what is lost. However, Portia's Mercy obscures not only the loss during the movement of translation but actually the aversion of a translation itself, of an interpretation and legal debate of Shylock's case. While Derrida indeed criticizes Portia’s strategy, he blames Shylock for resisting and preventing a "relevant" translation. According to Derrida's argument, Shylock, by insisting on the particularity of his pound of flesh, prevents the work of translation and thereby only strengthens his opponents. "By resisting this transcription, this transaction which is a translation, this relève, Shylock delivers himself into the grasp of the Christian strategy, bound hand and foot." ${ }^{10}$ With this insistence, Derrida's Shylock resists not only the Christian strategy but also the whole work of translation itself, the "labor [travail]," the "transferential and transformational travail," the "translation, as transaction and as transfer." 1 While he grants the problematic elements of the Christian strategy, for Derrida such a refusal of translation cannot be the answer: "In expressing all the evil that can be thought of the Christian ruse as a discourse of mercy, I am not about to praise Shylock when he raises a hue and cry for his pound of flesh and insists on the literalness of the bond." 12

In what follows, I offer an alternative reading of The Merchant of Venice, reversing Derrida's reading with his own terms, not least because the question of translation as Aufhebung indeed seems poignant with regard to the questions of law and interpretation that this volume poses. In my view, 
Shylock's case seems to offer both an account of the violent implications of the Aufhebung of law by mercy and an attempt at the deconstruction of the opposition assumed by it. Contrary yet somehow relevant to the setting that Derrida's text suggests, it is in fact Shylock who offers a translation, and it is the Christian call for mercy that prevents it. In this sense, the shift consists of linking the notion of insisting on "the letter of the law" not to any kind of "literal meaning" or a "scrupulous compliance with the law" but to an insistence on the textuality of the law. Textuality is here to be understood in Derrida's usual sense-a scripture not restricted to its literalness but on the contrary always open to and in fact in need of interpretation, translation, and sublation, while a "relevant translation" would be one that in some way pays tribute to what was lost in the process. As I would like to show, it is Shylock who, far from insisting on the literalness of his case and thereby refusing its translation, offers such translations. Following this reading will eventually invert the implicated Paulinian opposition of killing and giving life: As Shylock demonstrates, it is not mercy but rather the letter that "giveth life."

2

Against the grain of the traditional dichotomy of a deadening literal Jewish and an enlivening spiritual Christian conception of law, Shylock is first introduced to us as engaged in "lively" practices of interpretation and translation that refer us to an understanding of the "letter of the law" that is anything but deadening. In the third scene of act I, the Christian merchant of Venice Antonio turns to the Jew Shylock to borrow money from him. Shylock responds to this approach not by immediately accepting or declining Antonio's request but by performing an act of interpretation or translation, in which he offers another, wider context for Antonio's particular issue of money lending, interest, and usury.

\section{SHYLOCK}

When Jacob grazed his uncle Laban's sheep-

This Jacob from our holy Abram was,

As his wise mother wrought in his behalf,

The third possessor; ay, he was the third-

ANTONIO

And what of him? did he take interest? 
In this scene, which introduces Shylock for the first time, it is the Christian Antonio who is unwilling or unable to "translate" and transpose the practices of money lending at hand with regard to another context. In Shylock's response, we are confronted with a translation in the sense of the translatio of a metaphor: Shylock articulates the subject of loan and interest with the help of a biblical story of sheep breeding. This metaphorical context also provides a perspective for the two characters who are introduced as the Christian and the Jew: In this story, Shylock evokes the third born not just in the literal sense but as a metaphor for the marginalized, the underprivileged, that is, Shylock himself with regard to the privileged Christian Antonio, who understands neither the metaphorical transaction nor the implications this transaction provides for him or the situation at hand. Apparently neither trained nor interested in any kind of exegetical or translational practice, it is Antonio who in this instance insists on the literalness of his issue: "And what of him? did he take interest?" Shylock responds with a patient deliberation, leading a reluctant Antonio through an exercise of the art of interpretation of the law of usury by relating it to the biblical narrative of the overturning of the succession order.

\section{SHYLOCK}

No, not take interest, not, as you would say,

Directly int'rest. Mark what Jacob did:

When Laban and himself were compromised

That all the eanlings which were streaked and pied

Should fall as Jacob's hire, the ewes, being rank,

In the end of autumn turnèd to the rams,

And when the work of generation was

Between these woolly breeders in the act,

The skilful shepherd peeled me certain wands,

And in the doing of the deed of kind

He stuck them up before the fulsome ewes,

Who, then conceiving, did in eaning time

Fall parti-colour'd lambs; and those were Jacob's.

This was a way to thrive; and he was blest;

And thrift is blessing, if men steal it not.

(I.3.74-88)

This interpretation that Shylock displays, could, I would like to argue, be called a "transaction which is a translation" on more than one level. By way of a transaction, Shylock relates his own practice of lending money against 
interest to the narrative of the third-born yet skilled shepherd Jacob, who "produces" "interest" in the form of sheep from his work. His exegetical techniques—reading the "letter of the law," that is, its text-are far from any supposed "literalism" or "legalism" that would insist on the singular body of the original; rather, they showcase a particular practice of textual interpretation that explicates the defining ideas of a given nomos through narratives. It is in line with Jewish interpretation, or more precisely with "the project of early midrash," as Julia Lupton has outlined. ${ }^{13}$ The precept of the succession order in Deuteronomy-the "Mosaic code" that, as the Norton introduction to The Merchant of Venice emphasizes, "places a high value upon justice and emphasizes the importance of adhering to the letter of the law"-requires acknowledging the first-born son regardless of circumstances, even if he is the son of the hated wife. ${ }^{14}$ Yet Shylock tells a story exactly not of "rigorous enforcement" of or "scrupulous compliance" with this precept. He does not in this sense insist on the letter of the law, but returns to the "letter" in another, contrary sense. Shylock offers an interpretation of the law of usury by embedding that law narratively and relating it to a story of a third born who himself manages to resist the law (here: the order of succession) by a rather questionable practice of sheep breeding.

Shylock's exegesis is in line with the traditional practice of Jewish interpretation, as Pierre Legendre describes it, when he argues that since the Jews miss a pope as the "living voice of the law" to guarantee the truth, the signifier itself is much more radical and autonomous in the Jewish interpretative system. In his assessment, this explains the important role of the fables, that-like the stories of overturning the order of the first born and third born-demand interpretation and produce legal, poetical, and metaphorical meaning. ${ }^{15}$ Shylock's take seems to be an act of interpretation of the law that operates as a translation in Derrida's sense: negating, preserving, and elevating the original by relating it to this other narrative. In Shylock's case this kind of "relevant translation" does not operate through a mercy interrupting the legal procedure but through a narrative explication and translation of normative precepts. The relevant translation of justice is not mercy, it seems, but interpretation.

The succession order regulated by the book of Deuteronomy that Shylock takes up in his negotiations with Antonio is also a prominent example of one 
of the great essays on the subject of law and interpretation. Robert Cover uses it in his famous essay "Nomos and Narrative" to describe the practice of interpretation in a way very much in line with Shylock's display of exegesis. And just like Shylock's interpretation gestures toward a "life of the letter," Cover offers an alternative to the Paulinian opposition between the "dead letter" and the living spirit of the law. To explicate the life of the law, Cover highlights the productive tension between the normative order and the narratives that are supposed to elucidate it. With regard to the succession order in Deuteronomy, Cover goes so far as to suggest that, "indeed, all of the stories of the patriarchs revolve [in one way or another] around the overturning of the 'normal' order of successions." ${ }^{16}$ What makes a Jewish practice of interpretation especially interesting in this context is that both the precepts and those stories overturning them belong to the same corpus of the law as a text. Diverging from the Paulinian tradition, Cover links the engagement with the letter of the law to "life": The letter of the law is the medium of an abundance of interpretations and thereby the medium of jurisgenesis. From this perspective on the law and its interpretation, the letter does not so much "killeth" the law but on the contrary actually "giveth life." ${ }^{\prime 7}$ The practice of interpretation and the study of the law-the "paideia," as Cover calls it-is for Cover the foundation for a "life of the law" that coincides with, instead of being opposed to, the "letter of the law." In his description, using terms like legal DNA and juridical mitosis, he combines the paradigm of interpretation with biological terms pertaining to life and the processes of its evolution. According to this description, the paideic practices function as a medium of "jurisgenesis," as the field in which the "legal DNA" is replicated, reproduced, or modified and in which law is engendered. The "life of the law" is thus dependent on the paideic practices of interpretation, which allow for and thrive on difference. The imperial mode, on the other hand, consists of procedures of selection, negation, and restabilization: institutionalizing certain interpretations and cutting off others. The life of the law in this sense requires both an abundant proliferation of translations that can produce new law as well as a mechanism that can restrict this proliferation and institutionalize certain interpretations without, however, cutting off the productive movement of translation in such a way that jurisgenesis itself is cut off. ${ }^{18}$

In this dynamic of genesis and regulation, production and restriction, Cover ascribes to the court a special role as a doorkeeper and a governing site, with its procedures of intervening and institutionalizing that regulate 
and restrain the chaotic growth of the law in all its interpretations. Being in this central position, the court-that is, in this case, the Supreme Court-has the responsibility to face the challenge that the "demands of interpretation"19 produce: "Confronting the luxuriant growth of a hundred legal traditions, they assert that this one is law and destroy or try to destroy the rest." ${ }^{20}$ If interpretation follows a similar logic that Derrida ascribes to translation, then the court faces the challenge of asserting one interpretation against another, which is the challenge Derrida poses in the title of his text: "What is a 'relevant translation?" To be relevant in the richer sense that Derrida adumbrates, the selected interpretation should, however, not just negate the other options but somehow sublate and preserve them. Following this line of thought, the court has to face not only the demand that it has to decide but also the challenge that this decision has to reflect in some way the contesting normative views of the matter and has to find a resolution that addresses normative variety. Cover criticizes the Supreme Court in Bob Jones University v. United States- the paradigm case of his classic essay "Nomos and Narrative"-for failing to face such a more complex challenge. Instead of providing a space for allowing differing interpretations of the text of the law, in order to discuss, weigh, and deliberate their "relevance," and then enforce one while keeping the memory of the other, the court neglected its difficult task and jumped to a conclusion that prevented the challenge of facing other, possibly violent interpretations: "The apologetic and statist orientation of current jurisdictional understandings prevent courts from ever reaching the threatening questions." $^{21}$

Not in its decision, but in avoiding the discussion of and failing to reflect the alternative in the reasoning did the court in Cover's judgment fall short of its difficult task: Without weighing the relevance, however minimal, of the problematic and violent (i.e., racist) interpretation of Bob Jones University, the Court arrested the practice of controversial interpretation to prematurely enforce an existing hierarchy. Moreover, by merely enforcing one interpretation without considering a differing one, the Court also failed to acknowledge the necessary loss of the "original body" of the law in the specific interpretation it enforced. Finally, by referring to public safety and political factors as the main reasons underlying its decision, the Court left the practice of legal interpretation behind for arguments outside the text of the law that can hardly be challenged (translated, interpreted) in legal terms, thereby arresting the practice of legal debate. 
Avoiding the practice of interpretation in such a way is precisely, one could say, what happens in the court scene of The Merchant of Venice. ${ }^{22}$ Instead of facing the challenge of both fostering the "jurisgenerative" process productive of normative meaning and finding a decision that negates and preserves the variety of interpretations in favor of the enforced one, ${ }^{23}$ the Court shows itself to be informed by a normative Christian project and hence to be one of the sides it is supposed to assess. Instead of providing the space for the life and growth of differing interpretations, weighing and assessing them, the Venetian court fails to acknowledge its "relevance" by denying controversial textual exegeses, opening the sphere of the law up for political ruses. The Venetian court fails to face its paradoxical task-Derrida elsewhere calls it "impossible yet necessary" - to assert one interpretation against another. This task implies that the decision needs to acknowledge the relevance of each interpretation, including acknowledging what is lost of the law in its interpretation and the court's own precarious legitimacy ${ }^{24}$ to make such a decision. Reflecting its own precarious status as a selector for competing interpretations of the law ${ }^{25}$ means for the court to select carefully and while making a necessary decision, to protect the overall life and growth of the law. ${ }^{26}$ The Venetian court fails to realize this task in the attempt to arrest the act of legal interpretation, to leave the sphere of the law and to aim at something beyond the law (the soul of the subject behind the legal person), outside the law (political strategies), or above the law (mercy, elevating the law). It is an attempt to leave the realm of interpretation and the work of translation behind.

In line with the practice of interpretation with which he was first presented to us, Shylock does in fact challenge the Christian majority to a legal dispute: If they "own" their slaves, why can he not "own" part of Antonio's body?

\section{SHYLOCK}

What judgment shall I dread, doing no wrong?

You have among you many a purchased slave

Which, like your asses and your dogs and mules,

You use in abject and in slavish parts

Because you bought them. Shall I say to you

"Let them be free, marry them to your heirs.

Why sweat they under burdens? Let their beds 
Be made as soft as yours, and let their palates

Be seasoned with such viands."

$$
\text { (4.I.88-96) }
$$

Contrary to the view that he would cling to a literal interpretation, Shylock initiates an actual legal debate over the right of possession and thereby challenges the other side to show him where and how the law does not allow his claim. He offers possible routes of interpretation: comparing one case to another, as well as relating his particular case to a general norm.

It is remarkable that Shylock himself uses the term seasoned, in his challenge. He does so with reference to the context with which Derrida introduces his translation of Portia's "Mercy seasons Justice": the culinary context of flavors. For Derrida, it is the "the first reason to translate seasons with 'relève,' which effectively preserves the gustatory code and the culinary reference of to season, 'assaisonner': to season with spice, to spice. A seasoned dish is, according to the translation in the Robert dictionary, 'un plat relevé.' Justice preserves its own taste, its own meaning, but this very taste is better when it is seasoned or 'relevé' by mercy." ${ }^{27}$ In the rhetorical tradition, seasoning in this sense sometimes serves as a metaphor describing the mechanism of a metaphor itself, or of rhetoric as a whole. Plato's famous equation of rhetoric with cooking devalues rhetoric as a nonsubstantial addition (or supplement). Bassanio is the first to introduce the term in this way into the play and linking it to a dangerous supplement:

So may the outward shows be least themselves.

The world is still deceived with ornament.

In law, what plea so tainted and corrupt

But, being seasoned with a gracious voice,

Obscures the show of evil?

In this first usage of the crucial term in the play, the "seasoning of the law" indicates quite a different process than the one Portia later aims for: the seasoning of a legal plea in fact obscures its "show of evil." This first use of the term seasoned, in line with anti-rhetorical sentiments, seems to haunt Portia's own move when she claims that "Mercy seasons Justice." Her plea for mercy now may also be understood to be obscuring the evil Christian strategy, Shylock's conversion to Christian mercy to be obscuring justice or, rather, the lack thereof. Seasoning the law in this light may be understood as 
obscuring its cancellation. When Shylock uses the term, it is neither in the sense of obscuring, as Bassanio introduces it, nor in the sense of elevating, as Portia attempts to, but in its "literal meaning" of spicing; yet he uses it in the context of a legal interpretation of the right to own another human being (or part of it). In this context, to have one's "palate seasoned," turns out, however supplementary, to mark the ultimate distinction between being a "slave" and being a "free citizen" - a distinction the Christians have introduced and accepted in their laws, just as much as that between the Christians and the Jews. With this move-reflecting back his right to possess part of Antonio to Antonio's right to own a slave and using the notion of seasoning in this way for it-Shylock in some way performs an act of interpretation as seasoning. While Derrida portrays Shylock as the one resisting such acts of translation or interpretation, Shylock could very well be described as engaged in an act of "relevant translation."

It is, on the contrary, the Venetian court that deals with the challenge posed by Shylock by resisting any practice of interpretation. Instead of engaging in negotiations with Shylock's interpretation of contract law (which is certainly questionable), weighing its "relevance," its meaning, its limits, and its losses, discussing equity or the like, Portia simply asserts her claim, ${ }^{28}$ only to replace it with another case and to "season" this shift with Christian mercy, ${ }^{29}$ not least in the sense of "obscuring" it. When Portia enters the scene dressed up as a supposed expert on the law (also obscured, one could say), Shylock does not simply reject mercy but asks for its status within the debate of his case in court. Shylock resists the Christian attempt to leave this debate for a mercy from "above" and insists not on the dead letter of the law but on the continuation of the legal proceedings. ${ }^{30}$ Portia says, "Then must the Jew be merciful"; Shylock responds, "On what compulsion must I? tell me that" (4.I.I77-79). Shylock's demand for legal reasoning is repeatedly denied. While he himself may have motives for his claim that lie outside the law (revenge), Shylock's insistence is always a request to stay on this side of the law and legal reasoning. When the Christian party repeatedly aims for a subject behind his legal persona, by appealing for mercy or asking for his personal motives, he repeatedly resists this move beyond: "I'll not answer that" (4.I.4I). The Venetian court, rather than Shylock, resists the work of interpretation and translation: Instead of engaging in attempts at a responsible translation, the court surreptitiously and in what could be called an "obscured" dodge substitutes a question of criminal law for the civic law issues that Shylock raises by insisting on his bond. ${ }^{31}$ Shifting the trial in its 
constellation from civil to criminal law, from "breach of contract" to "attempted murder" and displacing Shylock from the position of the plaintiff to the accused, Portia does not mainly answer Shylock's supposed Jewish legalism with more legalism, as some commentators have suggested, ${ }^{32}$ but in fact grants him the undiscussed bond and by replacing it in the same instance, with another case, she arrests the possibility of any interpretation. Refusing to interpret Shylock's case by replacing the original body unaltered with another one, does not, in fact, seem like a "relevant" translation. Neither elevating nor preserving it, this obscured shift does not even allow for a mourning of what is lost.

The dodge also obscures a weakness of the Venetian law itself, that seems to allow any kind of private contract, even if it involves killing a citizen, while providing a totally unconnected law that not only contradicts this "absolute" freedom of contract but also rests on the political distinction between a citizen and an alien-a distinction that the contract law supposedly does not draw. What would be "relevant" at this point is an interpretation that could "translate" between the two bodies of law. Instead, the Venetian court abandons the order of a juridical process and turns to political and executional powers: Shylock is ordered to beg the Duke-the sovereign political instance-for the mercy that "seasons" justice. Moreover, this dodge is based on a law that apparently nobody knows: Unlike the civil contract law, it is not part of a practiced nomos but originates from a state of exception. Not unlike the case that Cover commented on in "Nomos and Narrative," the decision is legitimated by recourse to external factors (public safety and political reasons). What Portia's dodge does, in terms of Cover's conception, is not protecting the life of the law but "killing" it by arresting any "work of translation" that seems so "relevant" at this crossroad, against Shylock's ineffective attempts to "give it life."

5

When the Christian appeals to his mercy, only to then order him in turn to beg for political mercy himself, Shylock repeatedly answers the calls for "Christian" mercy with calls on their wit. Linking the skill of language to that of legal arguments, he thereby insists on a debate "relevant" to the court: When Gratiano says, "Can no prayers pierce thee?," Shylock responds, "No, none that thou hast wit enough to make" (4.I.I25-26). Bassanio with his misplaced prayers fails to provide anything that would have 
to be, as Shylock suggests, a "relevant" - that is, witty-translation of his legal case. When Gratiano offends Shylock, "O, be thou damned, inexorable dog," Shylock replies, "Thou but offend'st thy lungs to speak so loud. I Repair thy wit, good youth, or it will fall / To cureless ruin. I stand here for law" (4.I.I2I-4I).

What it would require to move Shylock in his so far undisputed position, he suggests, is wit. While Bassanio denies Shylock the status of being human for failing to prove spirit (that Bassanio himself in a performative contradiction obviously fails to show), Shylock insists on remaining on this side of the law, which is also the side of wit, that he, Shylock, questions in turn in Bassanio. Relating the legal arguments to "wit" is especially interesting with regard to an understanding of the letter of the law as its textuality. If wit is understood to be opposing a spiritual realm of prayers and itself as immanent to the law and (its) textuality, such an understanding would question the Paulinian opposition of the dead letter of the law and the spirit giving life. Insisting on the letter of the law is in this scenario not deadening but practicing wit and actually allowing for the work of interpretation and translation. Shylock has exhibited his interpretative, "lively" wit from the first scene in which we have encountered him.

In his essay "The Insistence of the Letter in the Unconscious," Jacques Lacan takes up the Paulinian phrase, but (almost in passing) deconstructs it by translating spirit with ésprit, and linking ésprit in a footnote to "wit" and "pun"- the textual form that deals with textual ambiguity per se. ${ }^{33}$ The title of the essay_- "The insistence of the letter" - presents us with a kind of reversal of the Paulinian phrase that Lacan mentions: It is the letter that "moves," insists, and makes the spirit "live." To prove spirit or Geist for Lacan means, by way of translating spirit by esprit and esprit by wit or Witz, to prove wit. Wit, however, is not a spirit that can be opposed to the letter but a spirit or life of the letter. It seems that a seasoning in Derrida's sense of a "relevant translation" would require wit, and in some way correspond to it. "Wit seasons justice" seems to be Shylock's answer to Portia's phrase.

The actual conversion to the Christian merciful "spirit" that happens instead of the (witty) legal interpretation that Shylock was aiming for does not exactly "give life" to Shylock: With "I am not well" Shylock leaves the stage and in some way the play to end. What seems to set this tone throughout is not, I would argue, a lack of Christian spirit, but on the contrary a lack of wit. That holds true even for the protagonist, the merchant of Venice Antonio, who seems not especially vitalized or animated by his Christian spirit 
and calls himself a "want-wit." In contrast to how Shylock is introduced in the play, displaying his excessive wit, this is how we encounter Antonio for the first time and how the play begins:

In sooth, I know not why I am so sad.

It wearies me, you say it wearies you,

But how I caught it, found it, or came by it,

What stuff' 'tis made of, whereof it is born,

I am to learn;

And such a want-wit sadness makes of me

That I have much ado to know myself.

Not insisting on the letter of the law is what seems to "kill" in this play. Insisting on mercy to "season" justice makes Shylock "not well," while the lack of wit to "work the letter" seems to drain the life of the law as well as of the want-wit Antonio. Insisting on the letter of the law in this play turns out to mean, as my reading has suggested, to insist on the work of interpretation. Shylock does not reject mercy in some kind of blind adhering to a dead letter, but in his insisting on the complex challenge of interpreting what remains debatable, readable, and translatable and what should not be replaced by a supposedly "seasoning" "mercy from above." The Merchant of Venice ultimately suggests the possibility of another translation-even if it may never be a fully "relevant" translation, but maybe, rather, a witty one.

\section{NOTES}

I. Jacques Derrida, "What Is a 'Relevant' Translation?," Critical Inquiry 27 (200I): 174-200.

2. Ibid., I95. In the context of this article, Derrida is not concerned with the complicity and tension between law and justice that is at the center of his essay "Force of Law: The "Mystical Foundation of Authority," Cardozo Law Review II (I990). "Justice," rather, serves as a synonym of what the former article had called "the law."

3. Hegel's Early Theological Writings, trans. T. M. Knox (Philadelphia: University of Pennsylvania Press, 1971), 212.

4. Katharine Eisaman Maus, introduction to The Merchant of Venice, in The Norton Shakespeare: Based on the Oxford Edition, ed. Stephen Greenblatt et al. (New York: Norton, 1997), III4-I5; my emphasis.

5. It is Pierre Legendre's specific twist to point out that this Christian love needs 
and evokes Roman law and can thus not confine itself to opposing itself to the (dead) law. Christian love and Roman law, rather, form two complementary institutions.

6. See also Lisa Lampert, Gender and Jewish Difference from Paul to Shakespeare (Philadelphia: University of Pennsylvania Press, 2004), Io.

7. Derrida, "What Is a 'Relevant' Translation?," I94.

8. Ibid. For the Hegelian background, see Hegel's Early Theological Writings, trans. T. M. Knox (Philadelphia: University of Pennsylvania Press, 1971), 212: "This spirit of Jesus, a spirit raised above morality, is visible, directly attacking laws, in the Sermon on the Mount, which is an attempt, elaborated in numerous examples, to strip the laws of legality, of their legal form. The Sermon does not teach reverence for the laws; on the contrary, it exhibits that which fulfils the law but annuls it as law and so is something higher than obedience to law and makes law superfluous." In the further explication of the contrast of Christianity and Judaism, Hegel does not mention Shylock but, interestingly enough, Macbeth: "The fate of the Jewish people is the fate of Macbeth who stepped out of nature itself, clung to alien Beings, and so in their service had to trample and slay everything holy in human nature, had at last to be forsaken by his gods (since these were objects and he their slave) and be dashed to pieces on his faith itself" (205).

9. Ibid., I99.

Io. Ibid.

II. Ibid., I76.

I2. Ibid., I98; my emphasis.

I3. Julia Reinhard Lupton, Citizen-Saints: Shakespeare and Political Theology (Chicago: University of Chicago Press, 2005), 80. Michael Greenstein calls it "a more imaginative mode of interpretation" in "Breaking the Mosaic Code: Jewish Literature vs. the Law," Mosaic 27 (1994): 88.

I4. "If a man has two wives, one loved and the other hated, and both the loved and hated have borne him sons, but the first born is the son of the hated wifewhen he leaves his inheritance to his sons he may not prefer the son of the beloved wife over the elder son of the hated wife. He must acknowledge the first born son of the hated wife and give him the double portion. For he is the first fruit of his loins and to him is the birthright" (Robert M. Cover, "Nomos and Narrative," in Narrative, Violence, and the Law: The Essays of Robert Cover, ed. Martha Minow, Michael Ryan, and Austin Sarat [Ann Arbor: University of Michigan Press, 1993], II4).

I5. Pierre Legendre, "Die Juden interpretieren verrückt," in Vom Imperativ der Interpretation (Vienna/Berlin: Turia + Kant, 20I0), I82. Cf. Law, Text, Terror: Essays for Pierre Legendre, ed. Peter Goodrich, Lior Barshack, and Anton Schutz (New York: Routledge, 2006).

I6. Cover, "Nomos and Narrative," II5; my emphasis.

17. See Stéphane Mosès, The Angel of History: Rosenzweig, Benjamin, Scholem, trans. Barbara Harshav (Stanford, Calif.: Stanford University Press, 2009). 
I8. If the practice of interpretation can be understood in terms of Derrida's idea of translation, this second, imperial mode is somehow in line with how Derrida describes the canonization of certain translations, for example, the way in which his translation for Aufhebung has been canonized, against certain odds and to his own surprise.

I9. Cover, "Nomos and Narrative," I44.

20. Ibid., I55.

2I. Ibid., I59.

22. William Shakespeare, The Merchant of Venice, in The Norton Shakespeare: Based on the Oxford Edition, ed. by Stephen Greenblatt et al. (New York: Norton, I997).

23. Cover, "Nomos and Narrative," IIo.

24. According to Cover, an imperial law structurally rests on overturning or repressing another law, an overturning that-as Derrida has shown in Force of Law in his reading of Benjamin's Critique of Violence — can be legitimized only by itself and retrospectively.

25. According to Ronen Reichman, the stakes for judicial (as well as legislative) decision making is extremely high in the Talmudic legal discourse, and compared to this standard, the court scene in the Merchant seems especially problematic. See Ronen Reichman, "Aspects of Judicial and Legislative Decision-Making within the Talmudic Legal Discourse," in Talmudische Tradition und moderne Rechtstheorie: Kontexte und Perspektiven einer Begegnung, ed. Karl-Heinz Ladeur, Ino Augsberg, and Mohr Siebeck (Tübingen: Mohr Siebeck, 2013).

26. Cf. Ino Augsberg and Karl-Heinz Ladeur, "Der Buchstaben Tödtet, Aber der Geist Machet Lebending?," Rechtstheorie 40 (2009): 43I-7I.

27. Derrida, "What Is a 'Relevant' Translation?," I95.

28. Richard H. Weisberg, "The Concept and Performance of 'The Code' in the Merchant of Venice," in Shakespeare and the Law, ed. Paul Raffield and Gary Watt (Oxford: Hart, 2008), 289-98.

29. Cf. Anselm Haverkamp, Shakespearean Genealogies of Power: A Whispering of Nothing in Hamlet, Richard II, Julius Caesar, Macbeth, the Merchant of Venice, and the Winter's Tale (London: Taylor \& Francis, 2010), I09I7.

30. Ino Augsberg, "Shylocks Anspruch," Archiv für Rechts- und Sozialphilosophie, Beiheft, no. II4 (2007): 257-67.

3I. Rudolf von Jhering famously calls it a "lousy dodge" ("elender Winkelzug") (Rudolf von Jhering and Felix Ermacora, Der Kampf um's Recht [Berlin: Propyläen Verlag, I992], 263-64). See Augsberg, "Shylocks Anspruch," $264 n 36$.

32. See, for example, Lisa Lampert's interesting reading of the Merchant that analyzes the difference of gender and of Jewish and Christian identity by reference to their diverging hermeneutical practices in Gender and Jewish Difference from Paul 
to Shakespeare (Philadelphia: University of Pennsylvania Press, 2004). Donaldson and others have pointed out how Portia's insistence that not an iota of blood is to be shed subverts the assumption of Jewish literalism. See Laura E. Donaldson, "Launcelot's Feast: Teaching Poststructuralism and the New Mestiza," in Order and Partialities: Theory, Pedagogy, and the "Postcolonial," ed. Kostas Myrsiades and Jerry McGuire (Albany: State University of New York Press, 1995), 189. For a reading that conceives of the iota as a stand-in for the Jew itself, see again Lupton, Citizen-Saints, 92-94.

33. "Of course, as it is said, the letter killeth while the spirit giveth life. We can't help but agree ... ; but we should also like to know how the spirit could live without the letter. Even so, the pretentions of the spirit would remain unassailable if the letter had not shown us that it produces all the effects of truth in man without involving the spirit at all. It is none other than Freud who had this revelation" (Jacques Lacan, "The Insistence of the Letter in the Unconscious," Yale French Studies 36-37 [1966]: 112-47). On the relevance of the pun in Shylock, see Haverkamp, Shakespearean Genealogies of Power, I09-17. 
